\title{
Particle size and cholesterol content of a mayonnaise formulated by OSA-modified potato starch
}

\author{
Shiva GHAZAEI ${ }^{1}$, Maryam MIZANI ${ }^{2 *}$, Zahra PIRAVI-VANAK ${ }^{3}$, Mazdak ALIMI ${ }^{4}$
}

\begin{abstract}
Egg yolk was partially replaced $(0,25,50,75$, and $100 \%)$ with octenyl succinic anhydride (OSA)-modified potato starch in a reduced-fat mayonnaise formulation to curtail the problems associated with high cholesterol and induced allergic reactions. The physicochemical properties included parameters such as: $\mathrm{pH}$, fat content, and emulsion stability of the formulations analyzed. The samples with $75 \%$ and $100 \%$ egg yolk substitute showed the maximum emulsion stability ( $>95 \%$ after two of months storage), and they were selected according to cholesterol content, particle size distributions, dynamic rheological properties, microstructure, and sensory characteristic. A significant reduction (84-97\%) in the cholesterol content was observed in the selected samples. Particle size analysis showed that by increasing the amount of OSA starch, the oil droplets with the peak size of $70 \mu \mathrm{m}$ engulfed by this compound became larger. The rheological tests elucidated that in the absence of egg yolk, OSA starch may not result in a final product with consistent texture and that the best ratio of the two emulsifiers (OSA starch/egg yolk) to produce stable reduced-fat, low cholesterol mayonnaise is $75 / 25$. The microscopic images confirmed the formation of a stable cohesive layer of starch surrounding the oil droplets emulsified in the samples selected.
\end{abstract}

Keywords: octenyl succinic anhydride; cholesterol; mayonnaise; particle size distributions; rheological characteristics; microstructure.

Practical Application: The egg yolk has been partially replaced (0, 25, 50, 75,100\%) by octenyl succinic anhydride (OSA)modified potato starch in a reduced-fat mayonnaise formulation. The $\mathrm{pH}$, fat content, cholesterol content and emulsion stability, particle size distributions, dynamic rheology, microstructure properties of the formulations were analyzed and the results indicated that $100 \%$ substitution of egg yolk may not be desirable because of large droplet size, low consistency and poor sensory scores. The best ratio of the two emulsifiers to produce stable reduced-fat, low cholesterol mayonnaise would be $75 / 25$.

\section{Introduction}

Mayonnaise is one of the most popular types of sauces in the world. It is a semi-solid oil-in-water emulsion produced as a mixture of egg yolk, vinegar, oil and some other ingredients (Depree \& Savage, 2001). Egg yolk is a key ingredient because of its high emulsifying capacity which is related to the phospholipids, lipoproteins (LDL and HDL), and non-associated proteins (livetin and phosvitin) (Anton et al., 2007; Laca et al., 2010; Moros et al.. 2002).

Today, conscious consumers demand healthier and nutritious foods, and mayonnaise is often mentioned by health-related deliberations because of its high fat (70-80\%) and cholesterol content (Liu et al., 2007; Nikzade et al., 2012). Therefore, different attempts have been made to develop low cholesterol products with characteristics similar to those of real mayonnaise (Laca et al., 2010). Low cholesterol mayonnaise with no egg yolk have been produced using egg white and food grade emulsifiers resulting in a full-fat (>70\%) product (Dartey et al., 1990). Moros et al. (2002) used a reduced-cholesterol egg yolk in mayonnaise formulation and showed that the rheological parameters may be improved by reducing the level of cholesterol by $40-80 \mathrm{wt} \%$ (Moros et al., 2002). Plant-based proteins, such as soy bean and wheat proteins, have been used as emulsifiers in several studies to replace egg yolk in mayonnaise emulsion systems (Puppo et al., 2000; Ghoush et al., 2008). Garcia (2006) studied the cholesterol-lowering effect of rice bran oil on a mayonnaise type spread. Laca et al. (2010) developed a simple laboratory procedure for producing egg yolk granules with lower cholesterol content as an emulsifying agent in mayonnaise preparation. A combination of soy milk, gums, and mono- and diglycerides has been statistically formulated to replace the egg yolk in low cholesterol-low fat products (Nikzade et al., 2012). The effects of different ingredients in the formulation of reduced fat/cholesterol mayonnaise were reviewed by Zhen \& Boye (2013).

Modified starches from different sources are usually used as thickening agents to provide desired structures in food products (Silva et al., 2006). Octenyl succinic anhydride (OSA) starch is a new type of chemically modified starch with surface active properties (Zhu et al., 2013). It is produced by esterification of

${ }^{1}$ Food Science and Technology, Science and Research Branch, Islamic Azad University, Tehran, Tehran, Iran

${ }^{2}$ College of Food Science and Technology, Science and Research Branch, Islamic Azad University, Tehran, Tehran, Iran

${ }^{3}$ Faculty of Food Industry and Agriculture, Standard Research Institute, Karaj, Karaj, Iran

${ }^{4}$ Department of Food Science and Technology, Ayatollah Amoli Branch, Islamic Azad University, Amol, Iran

*Corresponding author: mizani1_2000@yahoo.com 
different sources of starch with anhydrous octenyl succinic acid under alkaline conditions (Tesch et al., 2002; Bao et al., 2003; Dokic, 2008). The hydrophobic short octenyl succinate side chains may be responsible for adsorption of the OSA starch molecules at the oil/water $(\mathrm{O} / \mathrm{W})$ interface, and the long amylopectin backbone protects the droplets against flocculation by the mechanism of steric stabilization. Unlike typical surfactants, OSA starch forms a strong film at the $\mathrm{O} / \mathrm{W}$ interface and provides a good resistance against re-agglomeration (Bhosale \& Singhal, 2006; Timgren, et al., 2013). Increasing the viscosity of the continuous phase in combination with the ability of adsorption at interfaces, enables OSA starch to act as a stabilizer and also as an emulsifier in $\mathrm{O} / \mathrm{W}$ emulsion systems. This type of modified starch has been approved as a food additive by the FDA and EU (Tesch et al., 2002). In 2012, a proposal for using OSA starch modified gum arabic as an emulsifier was assessed according to Health Canada guidelines. It has been proved that OSA starch produced from different plant sources may exhibit somewhat different functional properties (Timgren et al., 2013).

The main objective of this research was to investigate the effect of partial $(0,25,50,75$, and $100 \%)$ replacement of egg yolk with OSA potato starch on the emulsion stability, cholesterol content, particle size, linear viscoelastic, and organoleptic properties of reduced fat mayonnaise.

\section{Materials and methods}

Octenyl succinic anhydride (OSA) potato starch, Emulsiform CM20, was purchased from the National Starch Company, Denmark. Betulin (Sigma-Aldrich, Germany) was used as internal standard in the cholesterol test. All other chemical reagents were of analytical grade.

\subsection{Preparation of mayonnaise}

Reduced fat mayonnaise samples were formulated as a mixture of about $40 \%$ vegetable oil, $4.8 \%$ sugar, $1.5 \%$ salt, $2 \%$ potato starch, $0.4 \%$ mustard, $0.05 \%$ xanthan, $0.14 \%$ guar gum, $0.01 \%$ citric acid, $0.01 \%$ sorbate, $0.06 \%$ benzoate, and $4.5 \%$ vinegar. The egg yolk, OSA starch, and water were used in different samples as shown in Table 1. All of the mayonnaise samples were prepared according to the method briefly shown in Figure 1 and analyzed by the following physicochemical tests in triplicates.

Table 1. Ingredients, $\mathrm{pH}$, and fat content of mayonnaise samples ${ }^{(1)}$.

\begin{tabular}{|c|c|c|c|c|c|}
\hline \multirow[b]{2}{*}{ Samples $^{(2)}$} & \multicolumn{3}{|c|}{ Formulation Ingredients } & \multirow[b]{2}{*}{ Fat Content } & \multirow[b]{2}{*}{$\mathrm{pH}$} \\
\hline & $\begin{array}{l}\text { Egg } \\
\text { yolk } \\
(\%)\end{array}$ & $\begin{array}{c}\text { OSA } \\
\text { starch } \\
(\%)\end{array}$ & $\begin{array}{c}\text { Water } \\
(\%)\end{array}$ & & \\
\hline 0 & 5.000 & - & 41.440 & $41.45 \pm 0.218^{\mathrm{a}}$ & $3.97 \pm 0.005^{\mathrm{a}}$ \\
\hline 25 & 3.750 & 0.125 & 42.560 & $41.37 \pm 0.025^{\mathrm{ab}}$ & $3.74 \pm 0.005^{\mathrm{b}}$ \\
\hline 50 & 2.500 & 0.250 & 43.690 & $40.72 \pm 0.543^{\mathrm{bc}}$ & $3.68 \pm 0.005^{c}$ \\
\hline 75 & 1.250 & 0.375 & 44.810 & $40.71 \pm 0.115^{\mathrm{bc}}$ & $3.60 \pm 0.005^{\mathrm{d}}$ \\
\hline 100 & $-\cdots$ & 0.500 & 45.940 & $40.32 \pm 0.075^{c}$ & $3.48 \pm 0.005^{\mathrm{e}}$ \\
\hline
\end{tabular}

${ }^{1}$ The results are expressed as mean \pm standard deviation. Data followed by the same letter in a column are not significantly different. ${ }^{2}$ Samples are classified by percentage of egg yolk in each formulation.

\subsection{Chemical analyses}

The $\mathrm{pH}$ of the mayonnaise samples was measured at $25^{\circ} \mathrm{C}$ using a 500 Cyberscan $\mathrm{pH}$ meter system. The fat percentage of the mayonnaise samples was determined according to the method of Mistry and Hassan (Mistry \& Hassan, 1992).

\subsection{Emulsion stability}

Samples, each weighing $15 \mathrm{~g}$, were heated in centrifuge tube at $80^{\circ} \mathrm{C}$ for $30 \mathrm{~min}$ and then centrifuged at $5000 \mathrm{rpm}$ for $30 \mathrm{~min}$. The emulsion stability percentage was calculated according to Equation 1 (Mun et al., 2009; Nikzade et al., 2012):

Emulsion stability $(\%)=\left(\mathrm{F}_{1 /}, \mathrm{F}_{0}\right) \times 100$

$$
\begin{aligned}
& \mathrm{F}_{0}=\text { original weight of each sample } \\
& \mathrm{F}_{1}=\text { weight of the precipitated fraction }
\end{aligned}
$$

\subsection{Rheological behavior}

Rheological behavior of mayonnaise samples was studied in a Paar Physica rheometer (MCR 501, Anton Paar GmbH, Austria) at $25^{\circ} \mathrm{C}$ with serrated parallel plates measuring system (diameter $=25 \mathrm{~mm}$, gap $=1 \mathrm{~mm})$. Linear viscoelastic strain amplitude was determined as $0.4 \%$ using the strain sweep test (0.01-100\%) at a constant frequency of $1 \mathrm{~Hz}$; the frequency sweep test was performed at this constant strain over the range 0.01 to $100 \mathrm{~Hz}$.

\subsection{Particle size measurement}

Mayonnaise samples were analyzed using a Malvern particle size analyzer, Mastersizer 2000 according to the procedure described by Quintana et al. (2002). Droplet size measurements are reported as the Sauter mean diameter by Equation 2:

$$
d_{32}=\frac{\sum_{i=1}^{N} n_{i} d_{i}{ }^{3}}{\sum_{i=1}^{N} n_{i} d_{i}{ }^{2}}
$$

\subsection{Cholesterol measurement}

Betulin was added as an internal standard and then saponified with potassium hydroxide ethanolic solution; the unsaponifiable matter was extracted with ethyl ether. Sterols and triterpene dialcohols were fractionated by thin layer chromatography plates and then analyzed by gas chromatography (YL 6100 GC) with FID detector. The operating conditions were as follows: column temperature: $260 \pm 5^{\circ} \mathrm{C}$, injector temperature: $280-300{ }^{\circ} \mathrm{C}$, and detector temperature: $280-300^{\circ} \mathrm{C}$.

\subsection{Sensory evaluation tests}

Sensory characteristics including taste, color, odor, viscosity, or consistency, texture, appearance, and overall acceptability were evaluated by trained panelists based on a 9-point Hedonic scale ( 1 as the lowest and 9 as the highest score). The mayonnaise samples were served at room temperature in plastic cups. 12 trained panelists were requested to assess the samples according to the parameters stated in the sensory evaluation score sheet. 
(a)

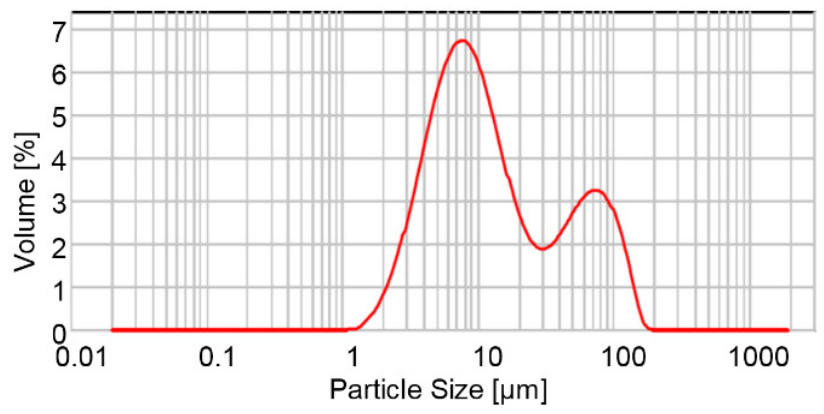

(b)

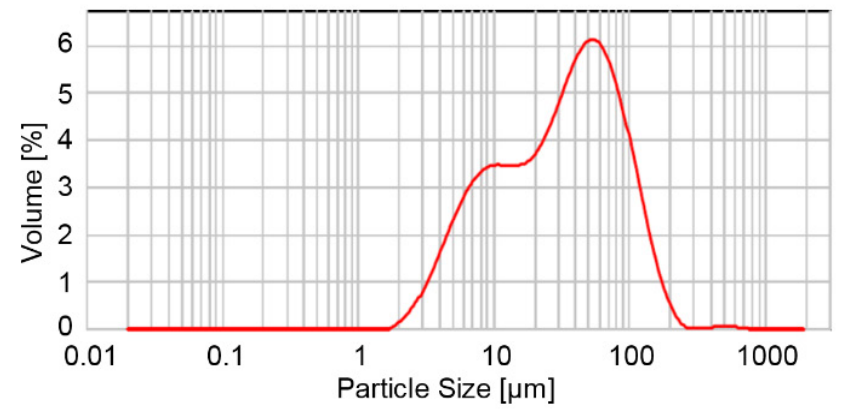

(C)

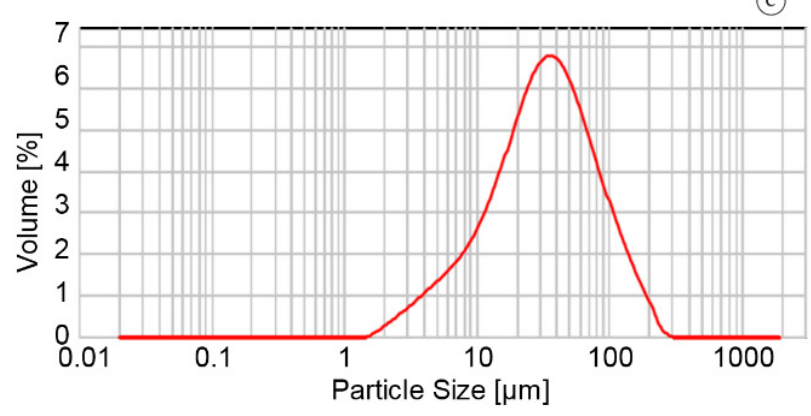

Figure 1. Particle size distribution curves of the control samples (a) and samples with $75 \%$ and $100 \%$ egg yolk substitute (b, c).

\subsection{Optical microscopy}

A reflective optical microscope (Motic BA300, Pol, UK) was used to investigate the microstructure of the mayonnaise samples. A drop of each sample was placed in the microscope glass slide, which was observed at a magnification of $40 \times$.

\subsection{Statistical analyses}

One-way analysis of variance (ANOVA) and Tukey's test $(p \leq 0.05)$ were used to analyze the test results. The analyses were conducted using a completely randomized design and the Minitab software, version16.

\section{Results and discussion}

The $\mathrm{pH}$ and fat content of the mayonnaise samples are given in Table 1, indicating that $\mathrm{pH}$ range of all of the samples was within 3.1-4.1, corresponding to USDA $\mathrm{pH}$ range for mayonnaise (United States Department of Agriculture, 2005). The results showed that by increasing the egg yolk substitute (from $25 \%$ to $100 \%$ ), the $\mathrm{pH}$ of the mayonnaise samples reduced significantly. Both the egg yolk and OSA potato starch have approximate $\mathrm{pH}$ value of 6 (Hui et al., 2009; Blitz et al., 2009), but since the sum of the weights of egg yolk and OSA starch used in the different mayonnaise formulations decreased with an increase in the amount of egg yolk replaced with OSA starch, lower $\mathrm{pH}$ values are expected in samples containing OSA as compared to that of the control. Although, the same amount of vegetable oil (30\%) was used in all formulations, the fat content is significantly reduced in the samples with higher amount of OSA starch, and this may be considered an another advantage for partial reduction of egg yolk as a fat-rich (31.8-35.5\%) ingredient
(Sikorski \& Kolakowska, 2003). Moros et al. (2002) reported the same result in mayonnaise produced with low cholesterol egg yolk (Moros et al., 2002).

The emulsion stability percentage of the mayonnaise samples after 1, 14, 30, 60, and 90 days of production is given in Table 2 . Egg yolk proteins and phospholipids act as excellent emulsifiers, and thus the best stability after up to two weeks was observed in the control sample formulated with $100 \%$ egg yolk (Jolivet et al., 2006; Magnusson \& Nilsson, 2011). On the other hand, for longer storage of up to 3 months, the sample with $100 \%$ OSA starch has shown better stability (Hockergard, 2011). Nevertheless, the lowest emulsion stability has been obtained for samples with $25 \%$ and 50\% egg yolk substitute, in which both emulsifying ingredients (egg yolk and OSA starch) compete for adsorption at the $\mathrm{O} / \mathrm{W}$ interfaces. Therefore, according to the results of Table 2 , the samples with $0 \%, 75 \%$, and $100 \%$ substituted-egg yolk, which showed the highest emulsion stability, were selected for further analyses to determine cholesterol content, particle size, and rheometric analysis.

Cholesterol content of the selected mayonnaise samples was determined after one month of production. According to the GC chromatograms, the peak of cholesterol has appeared in RT: $13.7288 \mathrm{~min}$ and the area under the peak is smaller with higher amount of substituted egg yolk. As it may be expected, cholesterol content of different samples has shown significant difference (Table 3), so that $75 \%$ and $100 \%$ substitutions have resulted in $84 \%$ and $97 \%$ reductions, respectively, as compared to control.

The particle size distribution curves of the control and the selected samples (75\% and 100\% substituted-egg yolk) 
Table 2. Emulsion stability of mayonnaise samples during storage ${ }^{1}$.

\begin{tabular}{cccccc}
\hline Storage time & \multicolumn{5}{c}{ Emulsion stability ${ }^{(1)}$} \\
\hline (Day) & Control & $25 \%$ & $50 \%$ & $75 \%$ & $100 \%$ \\
\hline 1 & $100.00 \pm 0.00^{\mathrm{a}}$ & $98.43 \pm 0.06^{\mathrm{c}}$ & $96.10 \pm 0.10^{\mathrm{d}}$ & $99.83 \pm 0.06^{\mathrm{a}}$ & $99.93 \pm 0.06^{\mathrm{b}}$ \\
14 & $100.00 \pm 0.00^{\mathrm{a}}$ & $98.07 \pm 0.06^{\mathrm{c}}$ & $95.43 \pm 0.12^{\mathrm{d}}$ & $99.83 \pm 0.06^{\mathrm{a}}$ & $98.46 \pm 0.06^{\mathrm{b}}$ \\
30 & $91.33 \pm 0.29^{\mathrm{e}}$ & $92.37 \pm 0.12^{\mathrm{d}}$ & $93.6 \pm 0.173^{\mathrm{c}}$ & $96.73 \pm 0.21^{\mathrm{b}}$ & $97.73 \pm 0.06^{\mathrm{a}}$ \\
60 & $89.67 \pm 0.58^{\mathrm{d}}$ & $93.90 \pm 0.10^{\mathrm{b}}$ & $92.07 \pm 0.06^{\mathrm{c}}$ & $96.23 \pm 0.06^{\mathrm{a}}$ & $96.93 \pm 0.06^{\mathrm{a}}$ \\
90 & $84.33 \pm 0.58^{\mathrm{d}}$ & $90.87 \pm 0.12^{\mathrm{b}}$ & $91.27 \pm 0.06^{\mathrm{b}}$ & $94.67 \pm 0.58^{\mathrm{a}}$ & $94.07 \pm 0.06^{\mathrm{a}}$ \\
\hline
\end{tabular}

${ }^{1}$ The results are expressed as mean \pm standard deviation. Data followed by the same letter in a column are not significantly different.

Table 3. Cholesterol content, particle size and rheological characteristics of the selected mayonnaise ${ }^{1}$.

\begin{tabular}{|c|c|c|c|c|c|c|c|}
\hline Sample & $\begin{array}{c}\text { Cholesterol } \\
\text { content } \\
(\mathrm{ppm})\end{array}$ & $\begin{array}{c}\mathrm{d}_{32} \\
(\mu \mathrm{m})\end{array}$ & $\begin{array}{c}\mathrm{G}_{0}^{\prime} \\
(\mathrm{pa})\end{array}$ & $\begin{array}{l}\Upsilon_{\text {LVE }} \\
(\%)\end{array}$ & $\begin{array}{c}\tan (\delta) \\
(-)\end{array}$ & $\mathrm{a}$ & $\mathrm{b}$ \\
\hline Control & $6823.041 \pm 0.000^{\mathrm{a}}$ & $8.38 \pm 1.78^{c}$ & $990.00 \pm 14.10^{\mathrm{ab}}$ & $1.27 \pm 0.13^{\mathrm{a}}$ & $0.20 \pm 0.01^{\mathrm{a}}$ & $1320 \pm 127.9^{c}$ & $0.125 \pm 0.002^{\mathrm{b}}$ \\
\hline $75 \%$ & $1024.413 \pm 0.000^{\mathrm{b}}$ & $16.37 \pm 1.18^{\mathrm{b}}$ & $1000.00 \pm 26.30^{\mathrm{a}}$ & $1.03 \pm 0.34^{\mathrm{b}}$ & $0.17 \pm 0.02^{\mathrm{b}}$ & $2203 \pm 35.1^{\mathrm{b}}$ & $0.107 \pm 0.002^{\mathrm{b}}$ \\
\hline $100 \%$ & $143.053 \pm 0.000^{c}$ & $18.40 \pm 1.18^{\mathrm{a}}$ & $709.50 \pm 21.30^{\mathrm{b}}$ & $2.07 \pm 0.11^{\mathrm{c}}$ & $0.17 \pm 0.01^{\mathrm{b}}$ & $644 \pm 182.3^{\mathrm{a}}$ & $0.160 \pm 0.007^{\mathrm{a}}$ \\
\hline
\end{tabular}

${ }^{1}$ The results are expressed as mean \pm standard deviation. Data followed by the same letter in a column are not significantly different.

are shown in Figure 1. Two main peaks, one at $10 \mu \mathrm{m}$ and the other at $70 \mu \mathrm{m}$, were observed in the control sample (curve a). It is likely that the larger peak $(10 \mu \mathrm{m})$ is associated with the oil droplets stabilized by a layer of egg yolk proteins in normal mayonnaise (Muller et al., 1998; Worrasinchai et al., 2006; Rayner et al., 2012), and the smaller peak $(70 \mu \mathrm{m})$ is associated with the modified potato starch which is used as a thickening agent. Juszczak et al. (2013) reported the particle size of granules of acetylated distarch adipate (ADA) corn and potato starches in ketchup suspension is in the range of 50-100 $\mu \mathrm{m}$. Whereas, in the sample with $75 \%$ egg yolk replacement (curve b), the main peak at $10 \mu \mathrm{m}$ is much smaller than that of the control because the oil droplets are mainly surrounded by OSA starch instead of egg yolk, and in the sample with $100 \%$ replacement (curve c), this peak seems to be completely vanished. On the other hand, by increasing the amount of OSA potato starch in mayonnaise formulations, the size of the peak at $70 \mu \mathrm{m}$ is increased. It may be suggested that this peak is associated with oil droplets surrounded by a layer of OSA starch. Rayner et al. (2012) studied the emulsions stabilized by OSA modified quinoa starch and reported droplet size in the range of 9-70 $\mu \mathrm{m}$. It is obvious that higher shear homogenization processes may produce smaller droplets. In the present study, a laboratory-scale mixer with moderate speed $(2500 \mathrm{rpm})$ was used in the mayonnaise preparation. The results of surface mean droplet diameter $\left(\mathrm{d}_{32}\right)$ in the mayonnaise samples indicate that egg yolk substituted by OSA starch may have resulted in much greater droplet size. It has been proved that the particle size characteristic of $\mathrm{O} / \mathrm{W}$ emulsion systems is mainly related to the emulsifier's ability to reduce the interfacial tension between the dispersed and continuous phases (Mc Clements, 2005). Egg yolk lecithin is a small molecular weight emulsifier and may be more active to reduce droplet size at the stage of emulsion formation than high molecular weight OSA starch molecules (Vincent et al., 1966; Krstonosic et al., 2011).
Therefore, the surface mean droplets diameter $\left(\mathrm{d}_{32}\right)$ of the control samples was almost $54 \%$ smaller than that of the samples formulated with $100 \%$ OSA starch (Table 3). It seems that better emulsification may be possible when both types of emulsifiers (small and large molecules) are used; therefore, the average droplet size of the sample with $75 \%$ substitution was $11 \%$ smaller than that of the sample containing OSA only. A similar result between OSA starch and Tween 80 was found by Dokic et al. (2008). Taherian et al. (2006) studied O/W emulsions stabilized by OSA starch and showed that as the amount of this ingredient was increased, bigger droplets were formed in the emulsion. A somewhat lower range of $\mathrm{d}_{32}(2-9 \mu \mathrm{m})$ in emulsions containing egg yolk proteins and OSA starch was reported by Magnusson \& Nilsson (2011). Nonetheless, the present study shows that larger particle sizes may be observed at low pH (4-4.5) due to oil droplet flocculation. Thaiudom \& Khantarat (2011) used OSA starch as a fat substitute in mayonnaise and concluded that the average particle size decreased with an increase in the starch concentration in the product. It seems that this different result is associated with a formulation in which the amount of egg yolk is maintained constant and OSA starch acts only as a fat and not as an egg substitute. Therefore, droplet sizes may be influenced mainly by egg yolk and also by OSA as a supporter in the stage of emulsion formation.

The results of the strain amplitude sweep tests are shown in Figure $2 \mathrm{a}$ and Table 3. All samples exhibited solid viscoelastic behavior $\left(G^{\prime}>G^{\prime \prime}\right)$. Structural gel strength $\left(G_{0}{ }^{\prime}\right)$ of both samples is not significantly different from that of the control (Table 3 ). The linear viscoelastic behavior range for mayonnaise-like systems may be indicative of the nature of intermolecular forces between the lipoproteins adsorbed around oil droplets (Quintana et al., 2002). Magnusson \& Nilsson (2011) studied interactions between OSA starch and egg yolk proteins at $\mathrm{O} / \mathrm{W}$ interfaces and showed that at low $\mathrm{pH}(\approx 4)$ a lower amount of OSA starch is adsorbed 

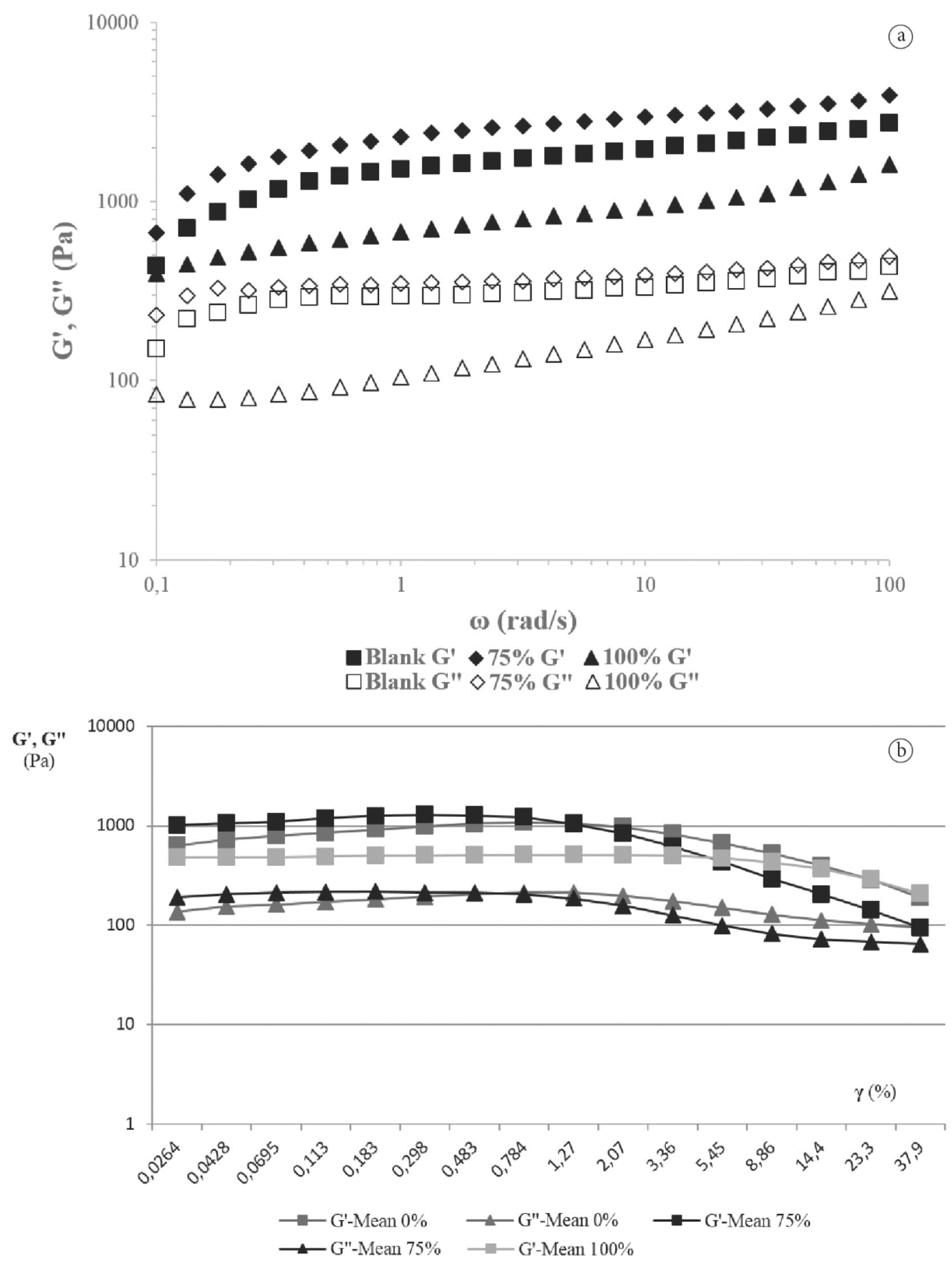

Figure 2. (a): Strain amplitude sweep of mayonnaise samples; (b): Frequency sweep of mayonnaise samples.

on droplets surface. Therefore, in the present research, the main interaction between two macromolecules may have occurred in the bulk of emulsion resulting in higher elastic characteristic (lower $\tan (\delta)$ ) and higher gel strength $\left(\mathrm{G}_{0}^{\prime}\right)$ in the sample with $75 \%$ substitution as compared to those of the control. On the other hand, weak intermolecular forces on the surface layer of oil droplets may be the reason for the lower $\Upsilon_{\text {LVE }}$ obtained for this sample.

Data of frequency sweep tests show a weak gel behavior in all of the mayonnaise formulations (Figure 2b), and the results 
of storage modulus versus frequency fitted well $\left(\mathrm{R}^{2}>97 \%\right)$ to power- law model $\left(G^{\prime}=\omega^{b}\right)$ (Table 3). Larger "a" coefficient for the $75 \%$ sample means higher consistency, and it corroborates the results of strain sweep test. On the other hand, a sample formulated with $100 \%$ OSA starch produced the lowest "a" and the highest " $b$ " due to the fact that in absence of egg yolk lipoproteins, OSA starch may not provide a desirable consistency in the mayonnaise texture in the final product.

The results of the sensory evaluation of the mayonnaise samples after one month of production are shown in Figure 3. No significant differences were observed in terms of taste, color, odor, texture, and appearance of the two mayonnaise samples and the control. The sample with $100 \%$ replacement shows the lowest viscosity with overall acceptability. However, the samples with $75 \%$ egg yolk substitute showed no significant difference in viscosity, and the same overall acceptability was reported by panelists as compared to that of the control.

Microscopic image of the sample with 75\% egg yolk substitution showed a closely packed layer of OSA starch clearly formed on oil/water interfaces (Figure 4), which is one of the main characteristics of particle- stabilized emulsions reported by Dejmek et al. (2012).

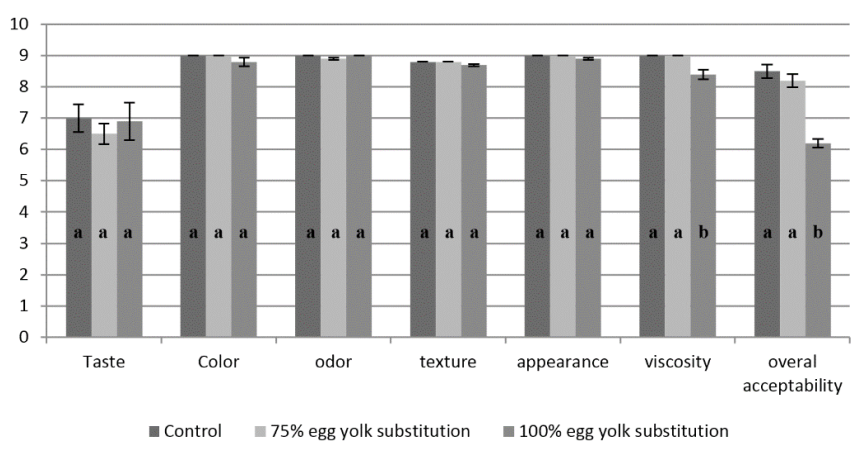

Figure 3. Organoleptic characteristics of mayonnaise samples after one month of production.

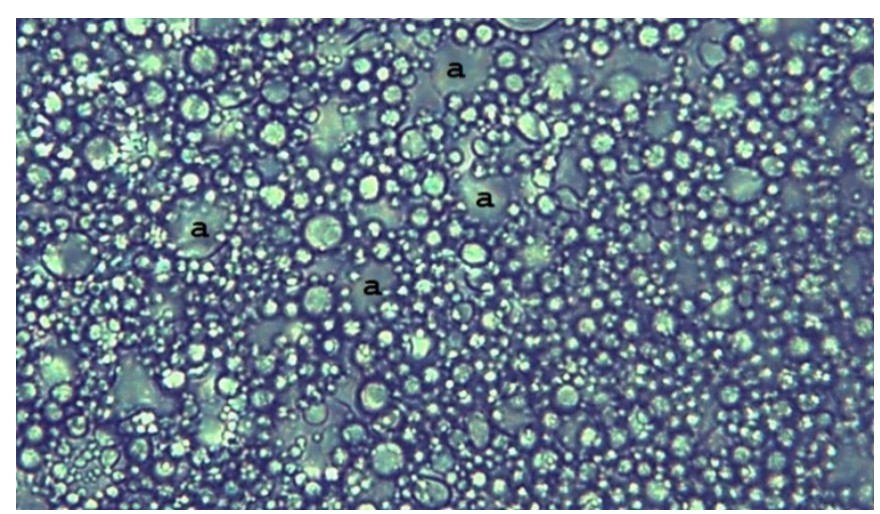

Figure 4. Microscopic image of mayonnaise sample with $75 \%$ substituted-egg yolk. (a) Packed layer of OSA starch formed on oil/water interfaces.

\section{Conclusion}

Today, there is a growing consumer demand for low fat, low cholesterol, healthier, and allergens-free food products. In this study, different concentrations of OSA potato starch were used in mayonnaise formulation as an emulsifier and egg yolk replacer. The optimum amount of OSA starch was determined based on the $84 \%$ reduction in cholesterol content, maximum consistency, good emulsion stability, and overall acceptability obtained. Since larger oil droplet sizes formed in the final emulsified product may have negative influenced its texture and storability, the application of higher shear force or the use of more surface-active emulsifiers in combination with OSA substitution may be considered in future studies.

\section{Acknowledgements}

The authors gratefully acknowledge the research ethics board of the Iranian Standard Research Institute (ISRI) and the R\&D Center of Behrouz Food Industries Company (Tehran, Iran) for technical support and Mr Naeeni (Institute for Color Science and Technology) for helpful assistance with particle size analysis.

\section{References}

Anton, M., Castellani, O., \& Guerin-Dubiard, C. (2007). Phosvitin. In R. Huopalahti, R. Lopez-Fandino, M. Anton \& R. Schade (Eds.), Bioactive egg yolk (pp. 17-23). Berlin, Heidelberg: Springer-Verlag.

Bao, J., Xing, J., Phillips, D. L., \& Corke, H. (2003). Physical properties of octenyl succinic anhydride modified rice, wheat, and potato starches. Journal of Agricultural and Food Chemistry, 51(8), 2283-2287. http:// dx.doi.org/10.1021/jf020371u. PMid:12670171

Bhosale, R., \& Singhal, R. (2006). Process optimization for the synthesis of octenyl succinyl derivative of waxy corn and amaranth starches. Carbohydrate Polymers, 66(4), 521-527. http://dx.doi.org/10.1016/j. carbpol.2006.04.007.

Blitz, H. D., Grosch, W., \& Schieberle, P. (2009). Food chemistry (4th ed.). Berlin, Heidelberg: Springer-Verlag.

Dartey, K., Trainor, M., \& Evans, R. (1990). U.S. US Patent 4948617A. East Hanover, NJ.

Dejmek, P., Timgren, A., Sjoo, M., \& Rayner, M. (2012). WO. WO Patent 2012/082065A1 MalmÖ, Sweden.

Depree, J. A., \& Savage, G. P. (2001). Physical and flavor stability of mayonnaise. Trends in Food Science \& Technology, 12(5-6), 157-163. http://dx.doi.org/10.1016/S0924-2244(01)00079-6.

Dokic, P., Dokic, L., Dapcevic, T., \& Krstonosic, V. (2008). Colloid characteristics and emulsifying properties of OSA starches. Progress in Colloid \& Polymer Science, 135, 48-56.

Garcia, K. M. (2006). Quality characterization of cholesterol-free mayonnaise-type spreads containing rice bran oil (Dissertação de mestrado). B.S. Chemical Engineering. Louisiana State University. Louisiana.

Ghoush, M. A., Samhouri, M., Al-Holy, M., \& Herald, Th. (2008). Formulation and fuzzy modeling of emulsion stability and viscosity of a gum-protein emulsifier in a model mayonnaise system. Journal of Food Engineering, 84(2), 348-357. http://dx.doi.org/10.1016/j. jfoodeng.2007.05.025.

Hockergard, A. (2011). The freeze-thaw stability of mayonnaise and the effect of octenyl succinic anhydride modified starch as emulsifier 
(Degree project work). School of Natural Sciences, Linnaeus University. Kalmar, Suécia.

Hui, R., Qi-he, Ch., Ming-liang, F., Qiong, X., \& Guo-qing, H. (2009). Preparation and properties of octenyl succinic anhydride modified potato starch. Journal of Agricultural and Food Chemistry, 114(1), 81-86. http://dx.doi.org/10.1016/j.foodchem.2008.09.019.

Jolivet, P., Boulard, C., Beaumal, V., Chardot, T., \& Anton, M. (2006). Protein components of low-density lipoproteins purified from hen egg yolk. Food Chemistry, 54(12), 4424-4429. http://dx.doi. org/10.1021/jf0531398. PMid:16756376

Juszczak, L., Oczadły, Z., \& Gałkowska, D. (2013). Effect of modified starches on rheological properties of Ketchup. Food Bioprocess Technology, 6(5), 1251-1260. http://dx.doi.org/10.1007/s11947012-0813-x.

Krstonosic, V., Dokic, L., \& Milanovic, J. (2011). Micellar properties of OSA starch and interaction with xanthan gum in aqueous solution. Food Hydrocolloids, 25(3), 361-367. http://dx.doi.org/10.1016/j. foodhyd.2010.06.014.

Laca, A., Saenz, M. C.., Paredes, B., \& Diaz, M. (2010). Rheological properties, stability and sensory evaluation of low cholesterol mayonnaise prepared using egg yolk granules as emulsifying agent. Journal of Food Engineering, 97(2), 243-252. http://dx.doi. org/10.1016/j.jfoodeng.2009.10.017.

Liu, H., Xu, X. M., \& Guo, Sh. D. (2007). Rheological, texture and sensory properties of low fat mayonnaise with different fat mimetic. Lebensmittel Wissenschaft and Technologies, 40(6), 946-954. http:// dx.doi.org/10.1016/j.lwt.2006.11.007.

Magnusson, E., \& Nilsson, L. (2011). Interactions between hydrophobically modified starch and egg yolk proteins in solution and emulsions. Food Hydrocolloids, 25(4), 764-772. http://dx.doi.org/10.1016/j. foodhyd.2010.09.006.

McClements, D. V. (2005). Food emulsions, practice, principles, and techniques (2nd ed). London: CRC Press.

Mistry, V. V., \& Hassan, H. N. (1992). Manufacture of nonfat yogurt from a high milk protein powder. Journal of Dairy Science, 75(4), 947-957. http://dx.doi.org/10.3168/jds.S0022-0302(92)77835-7. PMid:1578031

Moros, J. E., Franco, J. M., \& Gallegos, C. (2002). Rheological properties of cholesterol-reduced, yolk-stabilized mayonnaise. Journal of the American Oil Chemists' Society, 79(8), 837-843. http://dx.doi. org/10.1007/s11746-002-0567-6.

Muller, R. H., Benita, S., \& Bohm, B. (1998). Emulsions and nanosuspensions for the formulation of poorly soluble drugs. Germany: Medpharm Scientific Publishers Stuttgart.

Mun, S., Kim, Y. L., Kang, C. G., Park, K. H., Shim, J. Y., \& Kim, Y. R. (2009). Development of reduced-fat mayonnaise using 4alphaGTasemodified rice starch and xanthan gum. International Journal of Biological Macromolecules, 44(5), 400-407. http://dx.doi.org/10.1016/j. ijbiomac.2009.02.008. PMid:19428473

Nikzade, V., Mazaheri Tehrani, M., \& Saadatmand-Tarzjan, M. (2012). Optimization of low-cholesterol-low-fat mayonnaise formulation: Effect of using soy milk and some stabilizer by a mixture design approach. Food Hydrocolloids, 28(2), 344-352. http://dx.doi. org/10.1016/j.foodhyd.2011.12.023.
Puppo, M. C., Sorgentini, D. A., \& Anon, M. C. (2000). Rheological study of dispersions prepared with modified soybean protein isolates. Journal of the American Oil Chemists' Society, 77(1), 63-71. http:// dx.doi.org/10.1007/s11746-000-0010-z.

Quintana, J. M., Califano, A. N., Zaritzky, N. E., \& Partal, P. (2002). Effect of salt on the rheological properties of low-in-fat $\mathrm{O} / \mathrm{W}$ emulsions stabilised with polysaccharides. Food Science and Technology (Campinas.), 8(4), 213-221.

Rayner, M., Sjöö, M., Timgren, A., \& Dejmek, P. (2012). Quinoa starch granules as stabilizing particles for production of Pickering emulsions. Faraday Discussions, 158, 139-155, discussion 239-266. http://dx.doi.org/10.1039/c2fd20038d. PMid:23234165

Silva, G. O., Takizawa, F. F., Pedroso, R. A., Franco, C. M. L., Leonel, M., Sarmento, S. B. S., \& Demiate, I. M. (2006). Physicochemical characteristics of modified food starches commercialized in Brazil. Food Science and Technology (Campinas.), 26(1), 188-197. http:// dx.doi.org/10.1590/S0101-20612006000100030.

Sikorski, Z. E., \& Kolakowska, A. (2003). Chemical and functional properties of food lipids. NewYork: CRC.

Taherian, A. R., Fustier, P., \& Ramaswamy, H. S. (2006). Effect of added oil and modified starch on rheological properties, droplet size distribution, opacity and stability of beverage cloud emulsions. Journal of Food Engineering, 77(3), 687-696. http://dx.doi.org/10.1016/j. jfoodeng.2005.06.073.

Tesch, S., Gerhards, Ch., \& Schubert, H. (2002). Stabilization of emulsions by OSA starches. Journal of Food Engineering, 54(2), 167-174. http:// dx.doi.org/10.1016/S0260-8774(01)00206-0.

Thaiudom, S., \& Khantarat, K. (2011). Stability and rheological properties of fat-reduced mayonnaises by using sodium octenyle succinate starch as fat replacer. Procedia Food Science, 1, 315-321. http://dx.doi.org/10.1016/j.profoo.2011.09.049.

Timgren, A., Rayner, M., Dejmek, P., Marku, D., \& Sjöö, M. (2013). Emulsion stabilizing capacity of intact starch granules modified by heat treatment or octenyl succinic anhydride. Food Science and Nutrition, 1(2), 157-171. http://dx.doi.org/10.1002/fsn3.17. PMid:24804025

United States Department of Agriculture - USDA (2005). Mayonnaise, salad dressing and tartar sauce. Commercial item description (CID). Washington: USDA/FSIS.

Vincent, R., Powrie, W. D., \& Fennema, O. (1966). Surface activity of yolk, plasma and dispersions of yolk fractions. Journal of Food Science, 31(5), 643-648. http://dx.doi.org/10.1111/j.1365-2621.1966.tb01919.x.

Worrasinchai, S., Suphantharika, M., Pinjai, S., \& Jamnong, P. (2006). $\beta$-Glucan prepared from spent brewer's yeast as a fat replacer in mayonnaise. Food Hydrocolloids, 20(1), 68-78. http://dx.doi. org/10.1016/j.foodhyd.2005.03.005.

Zhen, M., \& Boye, J. I. (2013). Advances in the design and production of reduced-fat and reduced-cholesterol salad dressing and mayonnaise: a review. Food Bioprocess Technology, 6(3), 648-670. http://dx.doi. org/10.1007/s11947-012-1000-9.

Zhu, J., Li, L., Chen, L., \& Li, X. (2013). Nano-structure of octenyl succinic anhydride modified starch micelle. Food Hydrocolloids, 32(1), 1-8. http://dx.doi.org/10.1016/j.foodhyd.2012.11.033. 